\title{
Fertility, ovulation and maturation of eggs in mares injected with HCG
}

\author{
S. K. Webel*, V. Franklin, B. Harland and P. J. Dziuk \\ Department of Animal Science, University of Illinois, Urbana 61801, U.S.A.
}

\begin{abstract}
Summary. Pony mares were observed from January to August for incidence of oestrus, duration of oestrus, length of the oestrous cycle and for ovulation and fertility after injection of HCG. From January to 15 May most mares showed oestrus but the duration of oestrus was quite variable and few mares ovulated in response to HCG. From 15 May to 17 August oestrous cycles were more regular and ovulation was induced within $40-50 \mathrm{~h}$ by an intramuscular injection of 1500-5000 i.u. HCG. Pregnancy was established by one mating at a fixed time after HCG in 20 of 69 mares. Degenerate eggs were recovered from the oviducts of anoestrous, recently ovulated, mated, unmated and pregnant mares. The first polar body was formed before ovulation in 2 eggs and had not formed in 2 recently ovulated eggs flushed from the oviduct. The second polar body formed after sperm penetration 10-12 h after ovulation. After formation of pronuclei, the first cleavage division occurred at $20 \mathrm{~h}$ and the second at $32 \mathrm{~h}$ after ovulation. Oestrus was inhibited by progesterone administered by vaginal devices but occurred within 1-3 days in 12 of the 20 mares after withdrawal of the devices.
\end{abstract}

\section{Introduction}

The foaling rate of horses may be as low as 65 foals per 100 mares each year (Nishikawa, 1959; Hutton \& Meacham, 1968). In spite of an extensive literature on the reproductive physiology of the horse the reasons for this relatively low level of fertility are not completely known (Rowlands, Allen \& Rossdale, 1975). Because oestrus lasts from 4 to 11 days there has been conjecture as to when the mare should be bred during this period for optimum fertility (Andrews \& McKenzie, 1941; Berliner, 1959; Nishikawa \& Hafez, 1968). In practice, mares are bred daily or on alternate days during oestrus. This results in a great wastage of services of the male and may contribute to low fertility. The optimum time for breeding relative to ovulation has been estimated in the rabbit (Miller, Roche \& Dziuk, 1969), pig (Polge, Day \& Groves, 1968; Dziuk, 1970) and ewe (Dziuk, 1970) by inducing ovulation and timing inseminations. The time of mating relative to ovulation has been shown to have a marked effect on fertility.

Ovulation has been reported to occur within $48 \mathrm{~h}$ after an injection of $\mathrm{HCG}$ in oestrous mares with palpable mature follicles (Berliner, 1959; Loy \& Hughes, 1966), but the precise times of ovulation and maturation of the egg relative to an injection of HCG are unknown. Experiments were conducted to determine the time of ovulation and stages of egg maturation in mares given HCG at a fixed time relative to onset of oestrus and to examine whether pregnancies could be established by one fixed mating.

\section{Materials and Methods}

One hundred and ninety-one grade pony mares, weighing from 140 to $320 \mathrm{~kg}$ and with a wide variety of genetic and reproductive histories, were obtained from local auctions. Mares were checked for oestrus daily with an intact stallion and were considered to be in oestrus when they allowed the

\footnotetext{
* Present address: Abbott Laboratories, North Chicago, Illinois 60064, U.S.A.
} 
stallion to mount. Mares were injected intramuscularly with $4 \mathrm{ml} 0.9 \%(\mathrm{w} / \mathrm{v}) \mathrm{NaCl}$ or with 1500 to 5000 i.u. HCG in $4 \mathrm{ml} \mathrm{NaCl} 24 \mathrm{~h}$ after detection of oestrus. The mares were mated at $0,12,24$ or $36 \mathrm{~h}$ after injection and some were killed or laparotomized $36-72 \mathrm{~h}$ after injection of HCG for recovery of eggs. The oestrous behaviour of the other mares was observed and those not returning to oestrus were killed 30-40 days after mating.

At the time of killing or laparotomy the ovaries were examined for ovulation points and follicles. Eggs were flushed from the oviducts, uterus and follicles with $\mathrm{NaCl}$ solution. Eggs were isolated, examined and classified according to the stage of maturation in the fresh and stained states as described by Dziuk (1965). After 15 May, 20 mares received and retained for 20 days spiral vaginal devices containing progesterone. After withdrawal of devices the mares were observed for oestrus and were treated as described above.

These experiments were conducted from January through to August of each year over a 4-year period beginning in 1970 .

\section{Results}

Oestrous cycles observed from 1 January to 15 May were irregular in length with great variation in the intensity of oestrus. Fifty-one of 54 mares for whom observations were recorded during this time exhibited oestrus. The duration of oestrus ranged from 3 to 42 days, the mean being $16.3 \pm 12 \cdot 5$ (S.D.) days in 27 observed oestrous periods. The interval from the end of oestrus to the onset of the next oestrus was $14 \cdot 2 \pm 8.4$ days in 19 cycles. The interval from the end of one oestrus to the onset of the next oestrus in 6 mares injected with HCG was $14 \cdot 4 \pm 9 \cdot 5$ days.

In contrast, oestrous cycles during the normal breeding season from 15 May to 17 August were well defined and regular. In untreated mares the mean duration of oestrus in 51 observations was $7 \cdot 35 \pm 2.45$ days. The interval from the end of one oestrus to the onset of the subsequent oestrus was $16.64 \pm 3.25$ days in 17 recorded cycles. Injection of HCG shortened oestrus to $5 \cdot 7 \pm 2 \cdot 3$ days $(P<0.05)$ in 31 mares. Oestrus was inhibited in the mares by the vaginal devices containing progesterone but occurred within a few days after withdrawal of the implants: in 1 day in 7 mares, 2 days in 3,3 days in 2, 4 days in 1, 6 days in 2 and after 6 days in 5 mares.

The proportion of mares that had ovulated when examined at different intervals following $\mathrm{HCG}$ for three seasonal periods is shown in Table 1. One of eleven mares had ovulated when examined $48-50 \mathrm{~h}$ after $\mathrm{NaCl}$ injection during the period from $15 \mathrm{May}$ to 17 August. Mares in oestrus responded to HCG by ovulating during the breeding season (15 May to 17 August), but were nearly completely refractory and did not ovulate from January to April. The ovaries of oestrous mares observed during January, February and March contained few follicles greater than $1 \mathrm{~cm}$ in diameter. These follicles did not ovulate even after injection of as much as 5000 i.u. HCG. A transition period was observed from 1 April to 15 May when oestrus became more regular and intense and a few mares ovulated after HCG treatment.

Greater ovarian activity was noted during the transition period, with some ovaries containing follicles $1.5-2.5 \mathrm{~cm}$ in diameter. Mares observed after 15 May had either ovulated by $48 \mathrm{~h}$ after 1500 i.u. HCG or contained preovulatory follicles $2-3 \mathrm{~cm}$ in diameter. These preovulatory follicles were about to ovulate or contained activated ova. In contrast, few ova recovered from January to April had resumed meiosis $48-60 \mathrm{~h}$ after HCG. Approximately $50 \%$ of the mares injected with HCG from May to August had ovulated by $44 \mathrm{~h}, 75 \%$ by $48 \mathrm{~h}$ and $80 \%$ by $50 \mathrm{~h}$.

The stage of maturation of eggs recovered from follicles or oviducts of 32 mares killed at various times after injection of HCG from 1 April to 17 August is shown in Table 2. In addition to recently ovulated eggs, 0 to 10 degenerate eggs (Pl. 1, Fig. 1) were recovered from the oviducts. Degenerate eggs were found in oviducts which also contained fertilized eggs of normal appearance in mated mares, mares mated to a sterile male, in pregnant mares and in seasonally anoestrous mares with no recent ovulations.

Follicular oocytes and recently ovulated ova were surrounded by a large mass of sticky cumulus cells (Pl. 1, Fig. 2). This mass tended to be dispersed as eggs matured and was absent from the degen- 

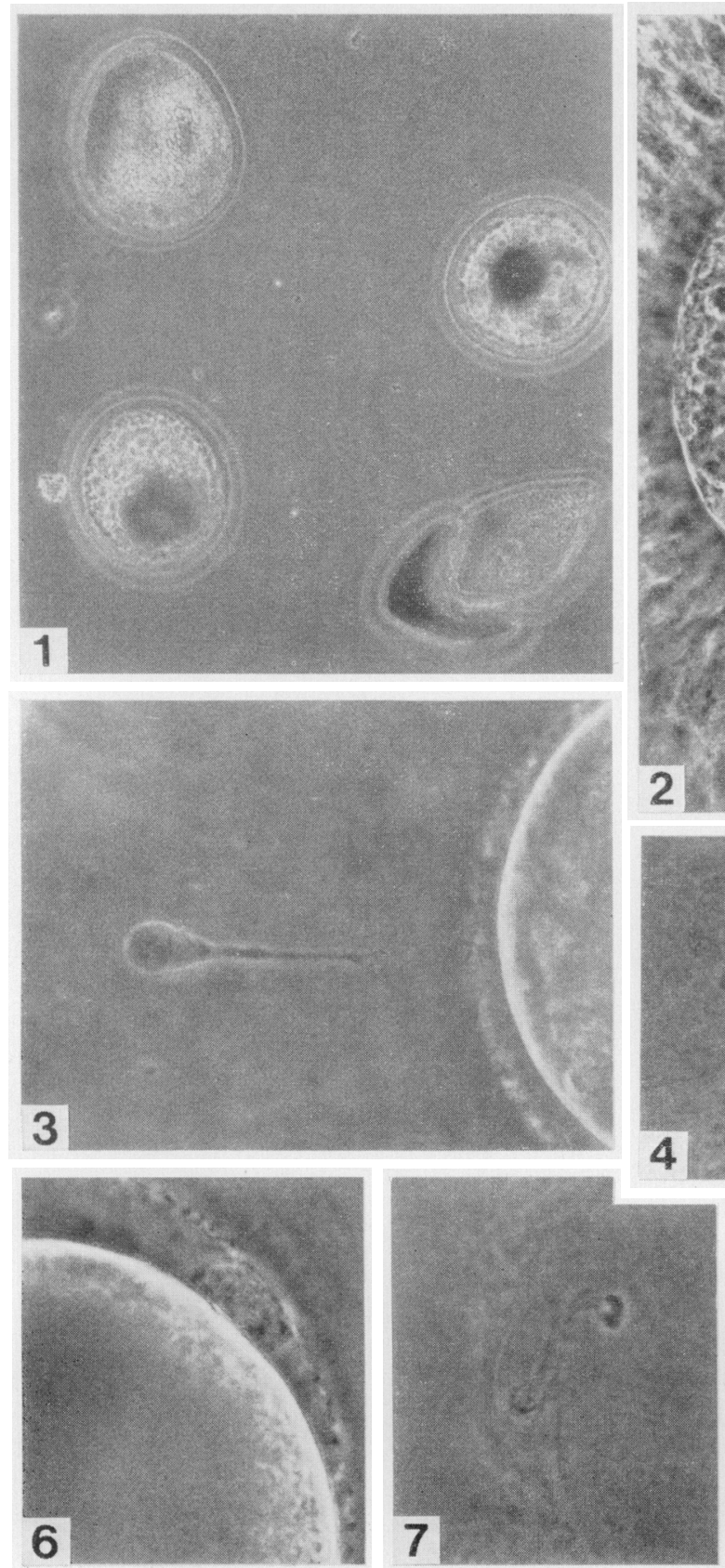
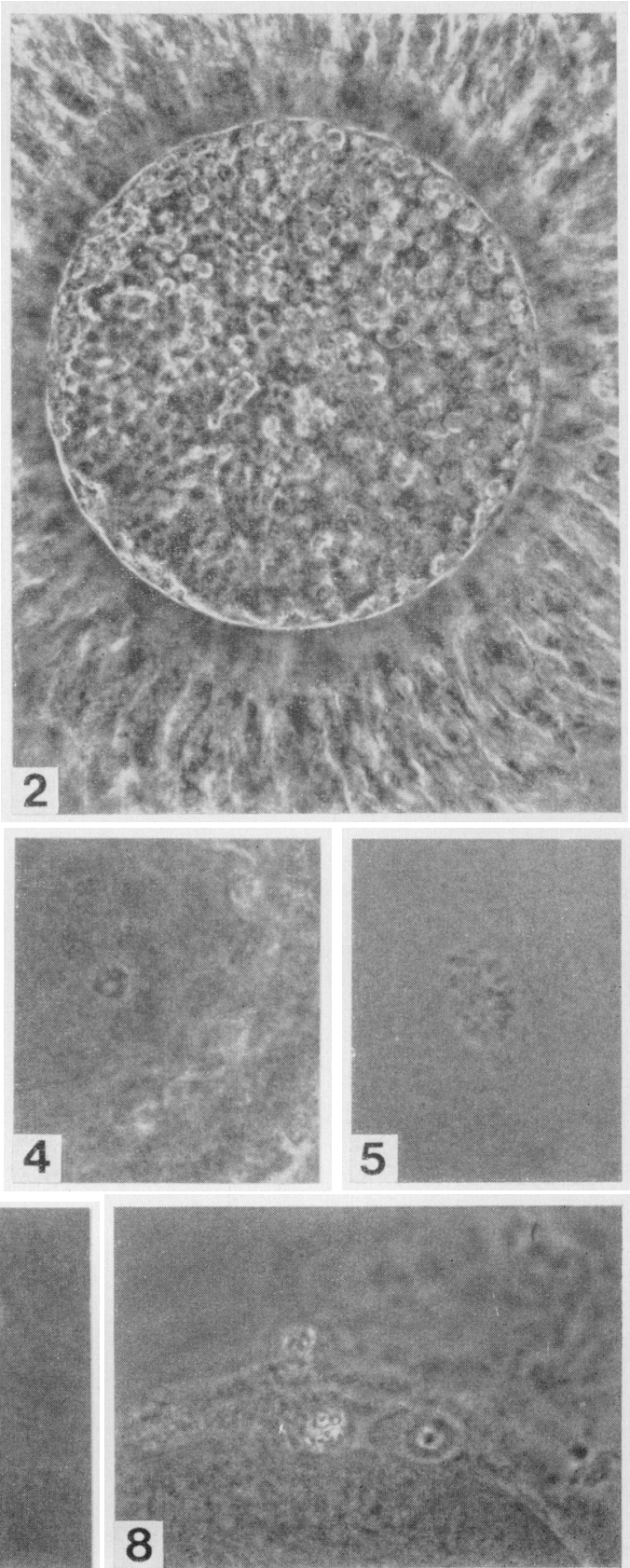

Fig. 1. Four degenerate eggs from one oviduct. $\times 58$.

Fig. 2. Egg with cumulus, from oviduct shortly after ovulation. $\times 290$.

Fig. 3. Cumulus cell with projections into zona pellucida. $\times 465$.

Fig. 4. Follicular egg hefore resumption of meiosis, stained. $\times 290$.

Fig. 5. First meiotic metaphase in follicular egg, stained. $\times 465$.

Fig. 6. First polar body at ovulation. $\times 465$.

Fig. 7. Formation of second polar body, stained. $\times 465$.

Fig. 8. First and second polar body, stained. $\times 465$ 
PLATL 2
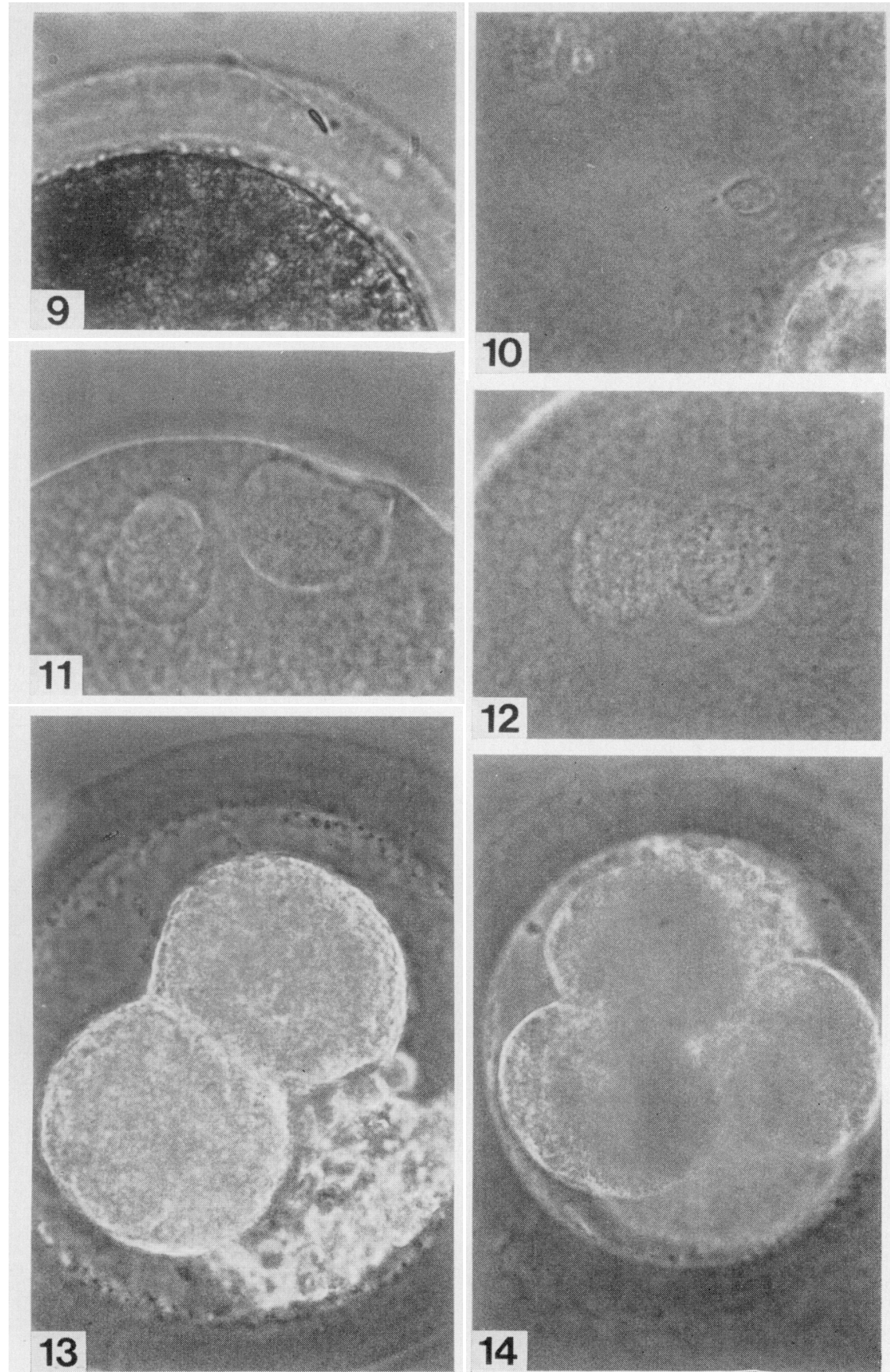

Fig. 9. Penetration of zona pellucida by spermatozoon. $\times 480$.

Fig. 10. Sperm head swelling on surface of egg cyloplasm, stained. $\times 480$.

Fig. 11. Pronuclei formation, stained. $\times 480$.

Fig. 12. Pronuclei fusion, stained. $\times 480$.

Fig. 13. Embryo, 2-cells. $\times 380$.

Fig. 14. Embryo, 4-cells, $\times 380$. 
Table 1. Proportion of mares ovulating/number of mares treated within $48 \mathrm{~h}$ of injection of HCG on Day 2 of oestrus in 1971

\begin{tabular}{|c|c|c|c|c|}
\hline \multirow[b]{2}{*}{ Season } & \multirow{2}{*}{$\begin{array}{c}\text { Dates of } \\
\text { treatment }\end{array}$} & \multicolumn{3}{|c|}{ Hours from injection to observation } \\
\hline & & $40-44$ & $44-48$ & $49-60$ \\
\hline Non-breeding & $\begin{array}{c}1 \text { January } \\
\text { to } \\
30 \mathrm{March}\end{array}$ & $0 / 2$ & $0 / 8$ & $1 / 11$ \\
\hline Transition & $\begin{array}{l}1 \text { April } \\
\text { to } \\
15 \mathrm{May}\end{array}$ & $0 / 0$ & $1 / 4$ & $7 / 19$ \\
\hline Breeding & $\begin{array}{c}16 \text { May } \\
\text { to } \\
17 \text { August* }\end{array}$ & $4 / 9$ & $8 / 12$ & $13 / 15 \dagger$ \\
\hline
\end{tabular}

* One of $11 \mathrm{NaCl}$-treated control mares ovulated by $48 \mathrm{~h}$ during the breeding season.

$\uparrow$ These observations were made at $49-50 \mathrm{~h}$.

Table 2. Stages of oocyte maturation (see Plate figures) at various times after injection of $\mathrm{HCG}$ or $\mathrm{NaCl}$ in mares treated after 1 April

\begin{tabular}{|c|c|c|c|c|c|c|c|c|c|c|c|}
\hline \multirow[b]{2}{*}{ Stage of egg* } & \multicolumn{10}{|c|}{ Time after HCG (h) } & \multirow{2}{*}{$\begin{array}{c}\text { Figure } \\
\text { reference }\end{array}$} \\
\hline & 40 & 42 & 44 & 48 & 52 & 54 & 56 & 60 & 66 & 72 & \\
\hline 4-cell & & & & & & & & & & 0 & 14 \\
\hline 2-cell & & & & & & & & & OO & & 13 \\
\hline Second polar body formed & & & 0 & & oo & & & 0 & & & 7,8 \\
\hline First polar body formed & & oo & & & & & & & & & \\
\hline & & FO & & OF & & 0 & & 0 & & & 6 \\
\hline Anaphase I & & $\mathbf{F}$ & & & & $\mathbf{0}$ & & & & & \\
\hline Metaphase I & $\mathbf{F}$ & & FSO & FFO & & & & & & & 5 \\
\hline Prophase I & F & & & FF & & & $\mathbf{F}$ & & & & \\
\hline $\begin{array}{l}\text { Vesicular } \\
\text { nucleus }\end{array}$ & & & & $\begin{array}{l}\text { SS } \\
\text { SS }\end{array}$ & & & & & & & 4 \\
\hline
\end{tabular}

* Origin of egg: $\mathrm{F}=$ follicle after $\mathrm{HCG} ; \mathrm{O}=$ oviduct after $\mathrm{HCG} ; \mathrm{S}=$ follicle after $\mathrm{NaCl}$.

erating eggs. Projections from cumulus cells extended into the zona pellucida (P1. 1, Fig. 3). With one exception, eggs recovered from the follicles of $\mathrm{NaCl}$-treated mares contained a vesicular nucleus and had not resumed meiosis (P1. 1, Fig. 4).

Unactivated oocytes similar to those observed in control mares were recovered from the follicles of most HCG-treated mares from January through to March. A few oocytes obtained from follicles measuring $1.5-2.5 \mathrm{~cm}$ had resumed meiosis but ovulation had not occurred by $72 \mathrm{~h}$ after HCG. In contrast, after 15 May the oocyte from the largest unovulated follicle near the ovulation fossa had resumed meiosis in mares given HCG. Four of the 6 mares killed at $44 \mathrm{~h}$ or later following HCG during the breeding season had follicles that had not ovulated (Table 2) but appeared to be very close to ovulation. In some mares the follicular wall was partly broken down and in 2 mares some of the cumulus mass was recovered from the oviduct but the egg was still present in the follicle. Oocytes recovered from follicles judged to be not near to ovulation or from follicles in mares which had already ovulated had not resumed meiosis.

Most preovulatory eggs recovered from HCG-treated mares during the breeding season were in prophase I or metaphase I (P1. 1, Fig. 5). Two eggs recovered from ovulating follicles had formed the first polar body (PI. 1, Fig. 6) but two eggs at metaphase I without polar bodies were recovered from the oviducts of other mares. These findings (see Table 2) suggest that formation of the first polar body occurs 44-48 h after HCG injection, near the time of ovulation. The second polar body forms (Pl. 1, 
Figs 7 and 8) after sperm penetration (Pl. 2, Figs 9 and 10) at about 10-12 h after ovulation. The pronuclei then form (Pl. 2, Figs 11 and 12) and the first cleavage occurs at $20 \mathrm{~h} \mathrm{(Pl.} \mathrm{2,} \mathrm{Fig.} \mathrm{13)} \mathrm{and} \mathrm{the}$ second cleavage at $32 \mathrm{~h}$ (Pl. 2, Fig. 14).

\section{Discussion}

The results of this study support previous observations that reproductive functions in the mare are influenced by season (van Niekerk, 1967; Ginther et al., 1972; Hughes et al., 1972). Although behavioural signs of oestrus occur at all seasons the signs during winter and early spring should not be confused with those of normal cycles observed during the breeding season. The conclusions in this study concur with those of Hughes et al. (1972) and van Niekerk (1967) that the interval from the end of oestrus to onset of the next oestrus was not greatly different between seasons. The follicular phase and length of oestrus were greatly influenced by season. Ovulation does not always accompany oestrus; in fact many mares exhibited heat when there were no large follicles in the ovaries.

Although oestrus will occur when only small follicles are present, large follicles are apparently essential to enable HCG to induce ovum maturation and ovulation: small follicles are refractory to stimulation of oocyte maturation and ovulation by HCG. Channing \& Kammerman (1973) have shown that pig granulosa cells from small follicles bind less HCG than cells from large follicles and this could explain the inability of HCG to induce ovulation in mares during the non-breeding season. That ovulation was readily induced with HCG during the breeding season and the oestrous period was shortened by 1 or 2 days is in agreement with the observations of Berliner (1959), Loy \& Hughes (1966) and Sullivan et al. (1973). Although the number of observations is small the inhibition of oestrus by vaginal devices and recovery of timed oocytes suggest that ovulation may be induced at an appointed time in the mare.

The time of ovulation after HCG $(40-48 \mathrm{~h})$ is not as precise as that reported for the sow or ewe (Dziuk \& Baker, 1962; Dziuk et al., 1964) but should permit a single timed insemination. Fertility should result if mares receive HCG on Days 2 or 3 of oestrus and are inseminated a few hours later, before ovulation. Because the present number of observations of fertility after a fixed mating are small a definite conclusion as to the optimum time cannot be reached at this time (Table 3 ).

Table 3. Interval from injection of $H C G$ to a single mating and conception

\begin{tabular}{ccc}
\hline & \multicolumn{2}{c}{ No. of mares } \\
\cline { 2 - 3 } Interval from HCG to mating (h) & Total & Pregnant (\%) \\
\hline 0 & 23 & $11(48)$ \\
12 & 27 & $5(19)$ \\
24 & 8 & $2(25)$ \\
36 & 11 & $2(18)$ \\
\hline
\end{tabular}

The evidence for time of polar body formation relative to ovulation is equivocal. Van Niekerk \& Gerneke (1966) claimed that the first polar body was formed before ovulation, whereas Hamilton \& Day (1945) claimed that ovulation preceded polar body formation. In the present study we have an equal number of observations supporting each conclusion. From the data of the above authors and Table 2, a time sequence for ovum maturation would be as follows: the first polar body forms about $44 \mathrm{~h}$ after $\mathrm{HCG}$ injection or very near the time of ovulation; the second polar body forms $10-12 \mathrm{~h}$ later after sperm penetration; the first cleavage occurs by $20 \mathrm{~h}$ and the second cleavage by $32 \mathrm{~h}$ after ovulation.

The finding of degenerate eggs in oviducts of mares in all reproductive states is in accord with the observation of van Niekerk \& Gerneke (1966) and Steffenhagen et al. (1972). The causes of this 
phenomenon cannot be readily explained except that fertilization apparently precipitates changes conducive to the transport of fertilized eggs through the oviducts while leaving the unfertilized oocytes in the oviduct.

\section{References}

Andrews, F.N. \& McKenzie, F.F. (1941) Estrus and ovulation and related phenomena in the mare. Res. Bull. Mo. Agric. Exp. Stn No. 329.

BERLINER, V.R. (1959) The estrous cycle of the mare. In Reproduction in Domestic Animals, pp. 267-289. Eds H. H. Cole \& P. T. Cupps. Academic Press, New York.

Channing, C.P. \& Kammerman, S. (1973) Characteristics of gonadotropin receptors of porcine granulosa cells during follicle maturation. Endocrinology 92, 531-540.

Dzıux, P.J. (1965) Timing of maturation and fertilization of the sheep egg. Anat. Rec. 153, 211-223.

DzıuK, P.J. (1970) Estimation of optimum time for inseminating gilts and ewes by double mating at certain times relative to ovulation. J. Reprod. Fert. 22, 277-282.

DzIUK, P.J. \& BAKER, R.D. (1962) Induction and control of ovulation in swine. J. Anim. Sci. 21, 697-699.

DziuK, P.J., Hinds, F.C., Mansfield, M.E. \& BaKeR, R.D. (1964) Follicle growth and control of ovulation in the ewe following treatment with 6-methyl-17acetoxyprogesterone. J. Anim. Sci. 23, 787-790.

Ginther, O.J., Whitmore, H.L. \& SQuire, E.L. (1972) Characteristics of estrus, diestrus and ovulation in mares and effects of season and nursing. Am. J. vet. Res. 33, 1935-1939.

Hamilton, N. \& DAX, F.T. (1945) Cleavage stages of the ova of the horse, with notes of ovulation. $J$. Anat. 79, 127-130.

Hughes, J.P., Stabenfeldt, G.H. \& Evans, J.W. (1972) Estrous cycle and ovulation in the mare. $J$. Am. vet. med. Ass. 161, 1367-1374.

Hutton, C.A. \& Meacham, T.N. (1968) Reproductive efficiency on fourteen horse farms. J. Anim. Sci. 27, 434-438.
LOY, R.G. \& HuGHEs, J.P. (1966) The effects of human chorionic gonadotrophin on ovulation, length of estrus and fertility in the mare. Cornell Vet. 56, 4150.

Miller, O.C., Roche, J.F. \& DZIUK, P.J. (1969) Estimation of the optimum interval between insemination and ovulation in the rabbit by double insemination. J. Reprod. Fert. 19, 545-546.

NishiKaWA, Y. (1959) Studies on Reproduction in Horses. Japan Racing Association, Tokyo.

Nishikawa, Y. \& Hafez, E.S.E. (1968) Reproduction in horses. In Reproduction in Farm Animals, pp. 266-276. Ed. E. S. E. Hafez. Lea and Febiger, Philadelphia.

Polge, C., DaY, B.N. \& Groves, T.W. (1968) Synchronization of ovulation and artificial insemination in pigs. Vet. Rec. 83, 136-142.

Rowlands, I.W., Allen, W.R. \& Rossdale, P.D. (Eds) (1975) Equine Reproduction. J. Reprod. Fert., Suppl. 23, 1-746.

Steffenhagen, W.P., Pineda, M.H. \& Ginther, O.J. (1972) Retention of unfertilized ova in uterine tubes of mares. Am. J. vet. Res. 33, 2391-2398.

Sullivan, J.J., Parker, W.G. \& Larson, L.L. (1973) Duration of estrus and ovulation time in nonlactating mares given human chorionic gonadotropin during three successive estrous periods. J. Am. vet. med. Ass. 162, 895-898.

VAN NIEKERK, C.H. (1967) Pattern of the oestrous cycle of mares. 1. The breeding season. 2. The duration of the oestrous cycle and oestrous period. J. S. Afr. vet. med. Ass. 38, 295-299.

van Niekerk, C.H. \& GerneKe, W.H. (1966) Persistence and parthenogenetic cleavage of tubal ova in the mare. Onderstepoort J. vet. Res. 33, 195-232.

Received 17 January 1977 